European Journal of Logistics, Purchasing and Supply Chain Management

Vol.8 No.1, pp.1-14, March 2020

Published by ECRTD UK

ISSN 2054-0930 (Print), ISSN 2054-0949 (Online)

\title{
DEMARKETING OF TOBACCO IN NIGERIA: THE ROLE OF THE MARKETING MIX
}

\author{
Ogunode Philips Olatunde, Abereola Samuel Niyi \& Adejimi, Seun Oyebola \\ Department of Marketing, the Federal Polytechnic, Ado-Ekiti, Ekiti State, Nigeria \\ E-mail: philips29g@yahoo.com \\ Contact Phone Number: +2348037181611
}

\begin{abstract}
The study is on demarketing of tobacco in Nigeria: the marketing mix perspectives. The study is a descriptive survey and it specifically examined the effect of product elaboration on consumers' attitude toward smoking, and intention to quit smoking; the effect of price elaboration on consumers' attitude toward smoking, and intention to quit smoking; the effect of place elaboration on consumers' attitude toward smoking, and intention to quit smoking and effect of promotion elaboration on consumers' attitude toward smoking, and intention to quit smoking. Primary data for this study was collected through questionnaires while secondary data was collected from the International tobacco Control (http://www.itcproject.org). Consumers of products of two tobacco companies operating in Nigeria constitute the population for the study. The two companies are: International Tobacco Company, Ilorin and Nigeria tobacco company, Ibadan. Since the population of smokers in Nigeria is unknown, convenience sampling technique was used to select 364 smokers from Ondo and Ekiti State. Inclusion criteria for this study defined smokers as those who have smoked atleast 100 sticks of cigarette in their life time and who still smoked at least once a day. Out of 364 questionnaires that were distributed, 355 (97.5\%) were returned. Data analysis was done using Cronbach's Alpha, frequency analysis, descriptive analysis, linear regression and one sample t-test. The linear regression tests show that elaboration of the 4Ps of marketing otherwise known as the marketing mix have significant effects on consumers' attitude toward smoking and intention to quit smoking. It was therefore recommended among others that the government of Nigeria should develop a suitable legislature aim at further reducing the acceptability and appeal of smoking; increase smoke-free places and decrease accessibility of people to tobacco.
\end{abstract}

KEY WORDS: demarketing, product, price, place, promotion

\section{INTRODUCTION}

Governments across the globe attempt to solve social problems through public policy initiatives that advocate one behavior over another. One of such social problems is smoking which is annually responsible for approximately 440,000 deaths in Nigeria (Centers for Disease Control and Prevention, 2002), and 4.8 million deaths worldwide (Ezzati and Lopez, 2003). Consumption of tobacco should be of great concern to consumers, governments and society at large, necessitating a rallying call for anti-consumption against tobacco.

Anti-consumption is in essence against consumption and can manifest through many different 
actions that are normally directed at products or producers. Reasons such as profit, politics, morals and environmental sustainability may motivate anti-consumption activities (Craig-Lees, 2006). Most anti-consumption movements originate at the consumer level, due to the frustration of an unequal balance of power between consumer groups and powerful national and multinational organizations. The anti-consumption movement regarding tobacco is different; in the last four decades, governments have been targeting the tobacco industry in a concerted demarketing drive (Moore, 2005). A recent global approach to concentrate efforts in demarketing tobacco resulted in the formation of the Framework Convention on Tobacco Control (FCTC: WHO, 2003) in 2003, under the auspices of the World Health Organization (WHO). To date, 168 countries, including Nigeria have signed the FCTC treaty with 131 of these ratifying the treaty within their countries. In response, the tobacco industry in combating governmental demarketing spent $\$ 12.5$ billion through advertising and promotions in the U.S. during 2002 (U.S. Federal Trade Commission, 2006), often targeting vulnerable groups such as youths and the marginally educated (Wigand, 2004). This study focuses on nation level demarketing of tobacco as an anti-consumption strategy against such high levels of marketing efforts by the tobacco industry.

Kotler and Levy (1971) define demarketing as "that aspect of marketing that deals with discouraging customers in general or a certain class of customers in particular on either a temporary or permanent basis". Kotler and Levy (1971) suggest that firms need to selectively demarket their products to deal with temporary shortages and excess demand as well as to reduce demand from "undesirable segments". Their focus was thus on how firms choose the optimal marketing mix (product, price, place, and promotion) to manage their long term relationship with their preferred customers. From a similar perspective, Cullwick (1975) also stressed the strategic role of the marketing mix elements in demarketing (see also Gerstner et al., 1993; Lawther et al., 1997). In contrast, demarketing tobacco through govern- mental interventions is concerned with an external agency (government) reducing or eliminating all consumer demand within a product class (tobacco) in competition with the marketing actions of the (tobacco) industry.

In a social marketing context, demarketing aims to deflate demand by discouraging consumption or use of products such as alcohol and cigarettes that pose health risks (Comm, 1997). Government use various demarketing strategies and instruments to curb smoking, including tobacco advertising bans (Saffer and Chaloupka, 2000), price increases (Andrews and Franke, 1991), and smoking bans (Wall, 2005). Whilst research exists in a demarketing context on individual elements of the marketing mix and their effect on smoking cessation, relatively little is known about how the 4Ps work in conjunction toward the goal of governmental demarketing including tobacco. Furthermore, research on how demarketing activities influence consumer behavior over time is scarce.

\section{Research Hypothesis}

The following hypotheses are stated in their null forms and they were tested in using correlation coefficients.

1. Product elaboration has no significant effect on consumers' attitude toward smoking, and intention to quit smoking. 
European Journal of Logistics, Purchasing and Supply Chain Management

Vol.8 No.1, pp.1-14, March 2020

Published by ECRTD UK

ISSN 2054-0930 (Print), ISSN 2054-0949 (Online)

2. Price elaboration has no significant effects on consumers' attitude toward smoking, and intention to quit smoking.

3. Place elaboration has no significant effects on consumers' attitude toward smoking, and intention to quit smoking

4. Promotion elaboration has no significant effects on consumers' attitude toward smoking, and intention to quit smoking.

\section{LITERATURE REVIEW}

\section{The Marketing Mix}

Marketing mix originates from the micro economics theory variable, price (Chong, 2003). McCarthy (1964) suggested marketing mix, known as the 4Ps, as a tool to implement marketing plans (Bennett, 1997). The marketing mix spells out the key decisions that managers make in order to adjust the products and services to the customers' demands. It is thus not a scientific theory but rather a theoretical framework. The 4Ps framework can be utilized to design both short term and long term strategies (Palmer, 2004). Kent (1986) defines the 4Ps of the marketing mix as "the holy quadruple of the marketing faith written in tablets of stone". Marketing mix has been found to be a significant determiner of theory and practical tools in marketing (Möller, 2006).

The primary factors that make the marketing mix a powerful approach are: marketing appears easy to handle with the availability of this framework. It also delegates marketing tasks to experts and separates the marketing domain from other organizational activities. And the elements of the marketing mix can be instrumental in altering a firm's competitive standing (Grönroos, 1994). The marketing mix framework also presents two major advantages. First, it is an important tool used to enable one to see that the marketing manager's job is, in a large part, a matter of trading off the benefits of one's competitive strengths in the marketing mix against the benefits of others. The other advantage of the marketing mix is that it helps in revealing the flip side of the tasks of the marketing manager. All managers are required to allocate accessible resources among various demands; the marketing manager on the other hand must delegate these resources among different competitive elements of the marketing mix. This in turn will enable the culmination of a marketing philosophy within the organization (Low and Tan,1995).

Möller (2006) however argued that the deficiencies of the 4Ps marketing mix concept, as the cornerstones of the traditional marketing management are subject to extreme criticism. Many critics reject the 4Ps altogether and propose other substitute frameworks.

The original marketing mix suggested by Borden constituted 12 elements namely: product planning; branding; pricing; channels of distribution; advertising; personal selling promotions; servicing; display; packaging; physical handling; and fact identification and investigation. Frey (1961) recommends dividing the marketing variables into 2: the offering (product, brand, price, packaging, and service) and the tools and methods (channels of distribution, advertising, personal selling, publicity and sales promotion). Conversely, Lazer and Kelly (1962) and Lazer, Culley and Staudt (1973) recommended three elements of the marketing mix: the 
European Journal of Logistics, Purchasing and Supply Chain Management

Vol.8 No.1, pp.1-14, March 2020

Published by ECRTD UK

ISSN 2054-0930 (Print), ISSN 2054-0949 (Online)

goods and services mix, the communication mix and the distribution mix. McCarthy (1964) clarified Borden's (1965) concept further and explained the marketing mix as a consolidation of all factors in the command of a marketing manager so as to meet the consumers' demands. $\mathrm{He}$ re- categorized Borden's 12 elements into four elements or 4Ps, namely product, price, promotion and place.

Particularly since the 1980s, a number of new introductions were made in the marketing mix. A fith P-People, was suggested by Judd (1987). Booms and Bitner (1980) introduced 3 new Ps (process, participants and physical evidence) to the existing 4 Ps to make the marketing mix framework applicable to services. Kotler (1986) recommended the addition of public opinion formation and political power to the existing 4Ps. Baumgartner (1991) recommends 15Ps. MaGrath (1986) introduced another 3 Ps (process management, personnel management and management of physical facilities). Goldsmith (1999) recommends 8Ps (product, price, place, promotion, personalization, participants, process and physical evidence). Vignalis and Davis (1994) recommend the $S$ of services to the marketing mix. For the purpose of this study, focus was on the four (4) P's of marketing which include Product, price, place and Promotion.

\section{Governmental Demarketing strategies}

Traditionally, the 4Ps of marketing refer to the various controllable elements of the marketing program. The underlying assumption is that a company needs to develop the right product, at the right price, to get it to their chosen market, in the right place and promote it to its target audience. To achieve de-marketing goals regarding their own customers, firms can address one or more marketing decision variables. For example, Kotler and Levy (1971) mention "steps to encourage de-consuming" including curtailing advertising expenditures and sales promotions, increasing the price and other conditions of sale, and adding time and expenses necessary for consumer to obtain the product. In the past, governments tended to use similar de-marketing actions in isolation. Recently, governments employ more comprehensive de-marketing activities to dissuade people from consuming tobacco and develop a de-marketing mix to combat smoking and smoking related behavior more effectively (see Hoek, 2004; Wall, 2005). Indeed, Wakefield and Chaloupka (2000) report that comprehensive tobacco control programs involving a range of coordinated and coexisting tobacco control strategies can work in a synergistic fashion to reduce smoking rates.

In the conceptualization of the de-marketing mix elements for this study, product is framed as product replacement and dis- placement. In essence this de-marketing variable aims to assist smokers in quitting by offering free or low-cost replacement products (e.g., nicotine replacement therapies) as well as support services (e.g., telephone quit-line and other information services). The de-marketing variable price is mainly delivered via increased taxation and hence sales price. From a consumer perspective price is a monetary sacrifice that results in a reduction of wealth (Erickson and Johansson, 1985; Jacoby and Olson, 1985). Similar to most product categories we can expect a negative relationship between cigarette price and consumption quantity (Erickson and Johansson, 1985; Lee et al., 2005). Conceptualized differently from distribution, place in this governmental de-marketing context is the prohibition of place of consumption through selective smoking bans such as on public transport, and broader clean air smoking bans in public places. In general, impediments in obtaining a product coupled with 
restrictions in consumption opportunities will result in reductions in consumption of the product (Anderson, 1972; Wakefield and Chaloupka, 2000). Promotion in this context is social counter advertising, mandatory warning labels as well as restrictions on tobacco advertising. Antismoking advertising and warnings highlighting the health harms associated with smoking are likely to negatively affect consumers' smoking- related attitudes and opinions. Consumers who engage with anti-smoking messages will likely alter their smoking-related attitudes and change their opinion about smoking to a less favorable position (Andrews et al., 2004).

\section{THEORETICAL BACKGROUND}

This study adopts a cognitive response approach to persuasion (e.g., Chaiken, 1987; Petty et al., 1981) to examine the impact of cognitive elaboration on attitudinal and behavioral change. Accordingly, persuasion takes effect when consumers generate and elaborate on their own thoughts in response to the de-marketing actions. Effective persuasion and attitude change require that consumers participate actively in the persuasion process and that favorable issue relevant thoughts (about the 4Ps) are generated (Eagly and Chaiken, 1993; Petty and Cacioppo, 1986). Attitude changes based on low levels of elaboration are known to be less durable and more open to subsequent attack (Petty et al., 1995; Petty and Krosnick, 1995) leading to failures in initiating or sustaining the desired behavior (i.e., quitting). Therefore high levels of consumer elaboration on the merits of quitting in response to the de-marketing 4Ps should have a negative effect on their attitude toward tobacco companies and attitudes toward smoking with a consequential positive effect on intention to quit.

\section{Research Methods}

This study adopted survey to collect data on each respondent and allows an examination of the extent to which elaboration will yield durable attitudinal change and higher levels of intention to quit. This study is a descriptive survey. Primary data for this study was collected through questionnaires while secondary data was collected from the International tobacco Control (http://www.itcproject.org). Consumers of products of two tobacco companies operating in Nigeria constitute the population for the study. The two companies International Tobacco Company, Ilorin and Nigeria tobacco company, Ibadan. Since the population of smokers in Nigeria is unknown, convenience sampling technique was used to select 364 smokers from Ondo and Ekiti state

Inclusion criteria for this study defined smokers as those who have smoked at least 100 sticks of cigarette in their life timeand who still smoked at least once a day. Based on the 2016 data, the mean age of respondents was 43 years $(\mathrm{SD}=13.66)$ and $78 \%$ were male. The average number of cigarettes smoked per day was $20(\mathrm{SD}=10.44)$. The data collected was analysed using linear regression.

\section{TEST AND RESULTS}

\section{Hypothesis One}

$\mathbf{H}_{\mathbf{0}}$ : Product elaboration has no significant effect on consumers' toward smoking, and intention to quit smoking. 
European Journal of Logistics, Purchasing and Supply Chain Management

Vol.8 No.1, pp.1-14, March 2020

Published by ECRTD UK

ISSN 2054-0930 (Print), ISSN 2054-0949 (Online)

Table 4.8 F-calculated for testing the significant of overall influence of product elaboration on consumers' attitudes towards smoking and intention to quit

\begin{tabular}{|l|l|l|l|l|l|}
\hline SV & SS & DF & MS & F-CAL & SIGN \\
\hline Regression & 0.234 & 1 & 0.234 & 23.082 & 0.010 \\
\hline Residual & 0.021 & 3 & 0.007 & & \\
\hline Total & & 4 & & & \\
\hline
\end{tabular}

Table 4.9 T-calculated for testing the individual influence of product elaboration on consumers' attitudes towards smoking and intention to quit

\begin{tabular}{|l|l|l|l|l|l|}
\hline Predictors & \multicolumn{2}{|l|}{$\begin{array}{l}\text { Unstandardized } \\
\text { coefficient } \\
\text { B Std.error }\end{array}$} & $\begin{array}{l}\text { Standardized } \\
\text { coefficient } \\
\text { Beta }\end{array}$ & T-calculated & Sign \\
\hline $\begin{array}{l}\text { Product } \\
\text { Elaboration }(\mathrm{x})\end{array}$ & 2.314 & 0.402 & 0.958 & 5.752 & 0.010 \\
\hline Constant & 3.285 & 0.089 & & 36.991 & 0.0000 \\
\hline
\end{tabular}

Table 4.10 Coefficient of determination for determining the overall contribution of product elaboration on consumers' attitudes towards smoking and intention to quit

\begin{tabular}{|l|l|l|l|}
\hline $\mathrm{R}$ & $\mathrm{R}^{2}$ & Adjusted $\mathrm{R}^{2}$ & $\begin{array}{l}\text { Standard error of the } \\
\text { estimate }\end{array}$ \\
\hline 0.958 & 0.917 & 0.889 & 0.084 \\
\hline
\end{tabular}

\section{Interpretation and Discussion of results}

The tables 4.8 to 4.10 above presented the results of the test statistics computed for the null hypothesis one. In table 4.8, the p-value of the F-statistics calculated for determining the overall significant of null hypothesis one of 0.010 was less than the critical value of 5\%. This revealed that the null hypothesis which stated that Product elaboration has no significant effect on consumers' attitude toward smoking, and intention to quit smoking was rejected. It could be asserted that there was a significant relationship between Product elaborations and consumers 'attitude toward smoking, and intention to quit smoking.Also, in table 4.9, the p-value of the tstatistics calculated for product elaborations of 0.010 was less than the critical value of 5\%. This implied that the null hypothesis which stated that Product elaboration has no significant effect on consumers' attitude toward the tobacco industry, attitude toward smoking, and intention to quit smoking was rejected. The regression coefficient computed for product elaborations of 2.314 indicated an existence of a positive relationship between product elaborations and consumers attitudes toward smoking and intention to quit smoking. The implication of this was that a unit increase in product elaborations might lead to a more than a unit intention to quit smoking. Furthermore, the coefficient of determination (R2) obtained for the test of hypothesis in table 4.10 of 0.917 revealed the fact that $91.70 \%$ of consumers' to quit smoking was as a result of product elaborations.

\section{Test of Hypothesis Two}

$H_{0}$ : Price elaborations has no significant effects on consumers' attitude toward smoking, and intention to quit smoking 
European Journal of Logistics, Purchasing and Supply Chain Management

Vol.8 No.1, pp.1-14, March 2020

Published by ECRTD UK

ISSN 2054-0930 (Print), ISSN 2054-0949 (Online)

Table 4.12 F-calculated for testing the significant of overall hypothesis two

\begin{tabular}{|l|l|l|l|l|l|}
\hline SV & SS & DF & MS & F-CAL & SIGN \\
\hline Regression & 0.183 & 1 & 0.183 & 124.310 & 0.0000 \\
\hline Residual & 0.006 & 4 & 0.001 & & \\
\hline Total & 0.189 & 5 & & & \\
\hline
\end{tabular}

Table 4.13 T-calculated for testing the individual significant of price on consumers' attitude toward smoking and intention to quit smoking

\begin{tabular}{|l|l|l|l|l|l|}
\hline Predictor & \multicolumn{2}{|l|}{$\begin{array}{l}\text { Unstandardized } \\
\text { coefficient } \\
\text { B Std.Error }\end{array}$} & $\begin{array}{l}\text { Standardized } \\
\text { coefficient }\end{array}$ & T-cal & Sign \\
\hline $\begin{array}{l}\text { Price } \\
\text { Elaboration }(\mathrm{X})\end{array}$ & 4.883 & 0.438 & 0.984 & 11.149 & 0.0000 \\
\hline Constant & 3.020 & 0.075 & & 40.066 & 0.0000 \\
\hline
\end{tabular}

Table 4.14 Coefficient of determination $\left(\mathrm{R}^{2}\right)$ for verifying the overall contribution of price elaboration on consumers' attitude toward smoking and intention to quit smoking

\begin{tabular}{|l|l|l|l|}
\hline$R$ & $R^{2}$ & Adjusted $R^{2}$ & $\begin{array}{l}\text { Standard error of the } \\
\text { estimate }\end{array}$ \\
\hline 0.984 & 0.969 & 0.961 & 0.038 \\
\hline
\end{tabular}

\section{INTERPRETATION AND DISCUSSION OF THE RESULTS}

The tables 4.12 to 4.14 above presented the results of the test statistics computed for the null hypothesis two. In table 4.12, the p-value of the F-statistics calculated of 0.0000 was less than the critical value of $5 \%$. This implied that the null hypothesis which stated that Price elaborations have no significant effects on consumers' attitude toward smoking, and intention to quit smoking was rejected. It could be asserted that there was a significant relationship between price elaborations and consumers' attitude toward smoking and intention to quit smoking. The imperative of price on consumer attitude toward purchases had been observed by many scholars in the field of management. Majority of this finding found out that there was a significant relationship between customers' attitude toward a product, intention to purchase prices charged by a company on its product. A company that was used to charged price of its product arbitrarily without puting appropriate consideration for its customers might not get the best from its customers in term of patronage. Customers (both retailers and final consumers) were always king as far as their decision to purchase products was concerned. Adebowale and Kabiru (2013) concluded that for any manufacturing company to continue to enjoy active participation pof its customers in the purchased and usage of its product there was need for such a company to make the price of its products reasonable enough for its customers and even if possible incurred lost on their behalf. Pricing had been observed by Smith (2014), Ayokunle (2012) and Kabiru (2010) to be significantly related to the satisfaction of customers. Furthermore, in table 4.13, the p-value of the t-statistics calculated for pricing of 0.0000 was less than the critical value of 5\%. This indicated that the null hypothesis which stated that Price elaborations have no significant effects on consumers' attitude toward smoking, and intention to quit smoking was rejected. The regression coefficient obtained for price of 4.883 was positive. This revealed that there was an existence of a positive relationship between prices of the selected tobacco companies and consumers attitude toward the purchase of 
European Journal of Logistics, Purchasing and Supply Chain Management

Vol.8 No.1, pp.1-14, March 2020

Published by ECRTD UK

ISSN 2054-0930 (Print), ISSN 2054-0949 (Online)

the products. The resultant effect of this was that a unit increase in price of tobacco products might lead to a more than a unit increase in consumers' intention to quit smoking and vice-versa.

\section{Test of Hypothesis Three}

Ho: Place elaboration has no significant effects on consumers' attitude toward smoking, and intention to quit smoking

Table 4.15 F-calculated for testing the overall influence of Null Hypothesis Three

\begin{tabular}{|l|l|l|l|l|l|}
\hline SV & SS & DF & MS & F-CAL & SIGN \\
\hline Regression & 0.075 & 1 & 0.075 & 143.482 & 0.0000 \\
\hline Residual & 0.002 & 4 & 0.001 & & \\
\hline Total & 0.079 & 5 & & & \\
\hline
\end{tabular}

Table 4.16 T-calculated for testing the individual significant of place elaboration on consumers' attitude toward smoking, and intention to quit smoking

\begin{tabular}{|l|l|l|l|l|l|}
\hline Predictor & \multicolumn{2}{|l|}{$\begin{array}{l}\text { Unstandardized } \\
\text { coefficient } \\
\mathrm{B}\end{array}$} & $\begin{array}{l}\text { Standardized } \\
\text { coefficient }\end{array}$ & T-calculated & Sign \\
\hline $\begin{array}{l}\text { Place } \\
\text { Elaboration }(\mathrm{X})\end{array}$ & 5.686 & 0.475 & 0.986 & 11.978 & 0.0000 \\
\hline Constant & 2.886 & 0.080 & & 36.224 & 0.0000 \\
\hline
\end{tabular}

Table 4.17 Coefficient of determination for determining the overall contribution of place elaboration on consumers' attitude toward smoking, and intention to quit smoking

\begin{tabular}{|l|l|l|l|}
\hline $\mathrm{R}$ & $\mathrm{R}^{2}$ & Adjusted $\mathrm{R}^{2}$ & $\begin{array}{l}\text { Standard Error of the } \\
\text { Estimate }\end{array}$ \\
\hline 0.986 & 0.973 & 0.966 & 0.023 \\
\hline
\end{tabular}

\section{Interpretation and Discussion of Results}

Tables 4.15 to 4.17 above presented the results of the test statistics computed for the null hypothesis three. In table 4.15, the p-value of the F-statistics calculated for testing the overall significant of the null hypothesis three of 0.0000 was less than the critical value of $5 \%$. This implied that the null hypothesis which stated that place elaboration has no significant effect on consumers' attitude toward smoking, and intention to quit smoking was rejected. It might be asserted that there was a significant relationship between place elaboration and consumers attitude to quit smoking.

In table 4.16, the p-value of the t-statistics calculated for testing the individual significant of place elaboration on consumers' attitude toward smoking of 0.0000 was less than the critical value of $5 \%$. This showed that the null hypothesis which stated that place elaboration has no significant effect on consumers' attitude toward smoking, and intention to quit smoking was rejected. In fact, the regression coefficient obtained for place elaboration of 5.686 was positive. This revealed that the relationship between place elaboration and consumers' intention to quit smoking was direct; hence, a unit increase in place elaboration might lead to a more than a unit positive attitude of consumers' toward smoking and vice-versa. 
European Journal of Logistics, Purchasing and Supply Chain Management

Vol.8 No.1, pp.1-14, March 2020

Published by ECRTD UK

ISSN 2054-0930 (Print), ISSN 2054-0949 (Online)

\section{Test of Hypothesis Four}

$\mathrm{H}_{\mathrm{o}}$ Promotion elaboration has no significant effects on consumers' attitude toward smoking, and intention to quit smoking.

Table 4.19 F-calculated for testing the overall significant of Promotion elaboration on consumers' attitude toward smoking, and intention to quit smoking.

\begin{tabular}{|l|l|l|l|l|l|}
\hline SV & SS & DF & MS & F-CAL & SIGN \\
\hline Regression & 0.064 & 1 & 0.064 & 15.585 & 0.017 \\
\hline Residual & 0.017 & 4 & 0.004 & & \\
\hline Total & 0.081 & 5 & & & \\
\hline
\end{tabular}

Table 4.20 T-calculated for testing the individual effect of Promotion elaboration on consumers' attitude toward smoking, and intention to quit smoking.

\begin{tabular}{|l|l|l|l|l|l|}
\hline Predictor & \multicolumn{2}{|l|}{$\begin{array}{l}\text { Unstandardized } \\
\text { coefficients }\end{array}$} & $\begin{array}{l}\text { Standardized } \\
\text { coefficients }\end{array}$ & T-cal & Sign \\
\hline $\begin{array}{l}\text { Promotion } \\
\text { Elaboration }(\mathrm{X})\end{array}$ & 6.950 & 1.761 & 0.892 & 3.948 & 0.0170 \\
\hline Constant & 2.705 & 0.295 & & 9.182 & 0.0010 \\
\hline
\end{tabular}

Table 4.21: Coefficient of determination $\left(R^{2}\right)$ for determining the overall contribution of Promotion elaboration on consumers' attitude toward smoking, and intention to quit smoking.

\begin{tabular}{|l|l|l|l|}
\hline$R$ & $R^{2}$ & Adjusted $R^{2}$ & $\begin{array}{l}\text { Standard Error of the } \\
\text { estimate }\end{array}$ \\
\hline 0.892 & 0.796 & 0.745 & 0.064 \\
\hline
\end{tabular}

\section{Interpretation and Discussion of Results}

Tables 4.19 to 4.21 presented the results of the test statistics computed for the null hypothesis four. In table 4.19, the p-value of the F-statistics calculated for testing the significant of overall hypothesis of 0.017 was less than the critical value of 5\%. This indicated that the null hypothesis which stated that there is no significant relationship between promotion elaboration and consumers' attitude toward smoking, and intention to quit smoking was rejected. It might be inferred that there was a significant relationship between promotion elaboration and consumers' attitude toward smoking and intention to quit smoking in the selected companies. Also, in table 4.20, the p-value of the t-statistics calculated for promotion elaboration of 0.0170 was less than the critical value of 5\%. This revealed that the null hypothesis which stated that promotion elaboration had no significant relationship with consumers' attitude toward smoking and intention to quit smoking was rejected. The regression coefficient computed for promotion elaboration of 6.950 showed an existence of a positive relationship between promotion elaboration and consumers' attitude toward smoking and intention to quit smoking. This implication of this was that a unit increase in promotion of tobacco might lead to a more than a unit increase in customers' positive attitude toward tobacco and vice-versa; hence, it could be asserted that promotion elaboration and consumers' attitude toward smoking were directly related. 


\section{CONCLUSION}

Social marketing can use the 4Ps in reverse to alter certain audiences' attitudes and behaviors. Furthermore, the influences of the 4Ps can be stable over time. The majority of smokers have a strong desire to quit. However, the addictive nature of tobacco acts as a powerful deterrent regarding initiating and sustaining quitting attempts. There- fore smokers' elaboration on product alternatives and support programs should result in a stronger intention to quit. Given the high levels of past quitting attempts and regret, such elaboration to generate thoughts about the undesirable addictive nature of tobacco should also result in negative attitudes both toward smoking and toward suppliers of such products.

In strictly economic terms, price increases have a dampening effect on demand (e.g., Varian, 1993). Levy et al. (2004) report that taxation induced large price increases can result in reducing smoking prevalence by at least 10\%. Maxwell (2002) reports that pricing has a direct effect on consumers' attitudes. However, price increases if attributed to government taxation should not have a significant effect on smokers' attitude toward tobacco companies.

One of the strongest governmental demarketing actions takes the form of smoking bans in public and workplaces. Levy et al. (2004) report that comprehensive clean-air regulations can potentially reduce smoking prevalence by $10 \%$ or more. Spending more time and effort on consuming cigarettes will reduce consumers' time for necessary activities such as self-maintenance, household maintenance, and leisure. Therefore restrictions on places to consume tobacco should be positively correlated with smokers' quit intention.

A ban on cigarette advertising through television and radio has been in place in the U.S. since 1971. However, Saffer and Chaloupka (2000) conclude that governmental demarketing of tobacco through advertising bans in Nigeria will have little effect on tobacco consumption unless a comprehensive ban is enforced. Research shows that government sponsored anti-smoking campaigns reduce positive percep- tions of smoking and hence have a direct negative effect on attitude toward smoking (Siegel and Biener, 2000). Further, campaigns that communicate the harmful effects of smoking are known to lead to changes in audience's smoking-related attitudes (Page and Colby, 2003).

\section{RECOMMENDATIONS}

The findings from this study indicate that the 4Ps are not treated in the same way as they are for profit -oriented organizations. This means that in social marketing and in anti-consumption contexts, the 4Ps are very useful in decreasing consumers' demand for goods and services. Therefore, social Marketer and government policy makers should see the 4Ps of marketing as useful variables in their own right because they are important drivers of smokers' smoking related attitudes and their quitting intention. Consequent upon the findings and conclusions of the study, the following recommendations are made:

1. The government of Nigeria should develop a suitable legislature aim at further reducing the acceptability and appeal of smoking; increase smoke-free places and decrease accessibility of people to tobacco.

2. The government should develop a national policy approaches for tobacco control, including the renewal national tobacco strategy. 
3. Government should strengthen it partnership with relevant stakeholders and other agencies to increase compliance activity, and discourage investment in tobacco industry.

4. The federal government should strengthen the capacity of local government to arrest and prosecute any smoker who smokes outside the areas permitted by law.

\section{REFERENCES}

Abdullah A.S. and Yam H.K. (2005). Intention to Quit Smoking, Attempts to Quit, And Successful Quitting Among Hong Kong Chinese Smokers: Population Prevalence And Predictors. American Journal of Health , 19(5):346-54.

Ajzen I.( 1980). The Theory of Planned Behavior. Organisation Behavior for Humanity Decision Process ;50:179-211.

Ajzen I, Fishbein M. Understanding Attitudes and Predicting Social Behavior. Englewood Cliffs, NJ: PrenticeHall.

Anderson Jr W. T.( 1972). Convenience Orientation and Consumption Behavior. Journal Of Retail;48(3):49_ 71.

Andrews R.L, Franke G.R. (1991). The Determinants of Cigarette Consumption: A Meta- Analysis. Journal Of Public Policy Marketing;10:81-100 [Spring].

Andrews C.J, Netemeyer R.G, Burton S, Moberg P.D, Christiansen A. (2004). Understanding Adolescent Intention To Smoke: An Examination Of Relation- Ships Among Social Influence, Prior Trial Behavior, And Anti-Tobacco Campaign Advertising. Journal of Marketing,;68:110-23 [July].

Baron R.M, Kenny D.A.( 1986). The Moderator-Mediator Variable Distinction in Social Psychological Research: Conceptual, Strategic, and Statistical Considerations. Journal of Social Psychology;51 (6):1173-82.

Bennett, A. R. (1997). The Five Vs A Buyer's Perspective of the Marketing Mix. Marketing Intelligence \& Planning,15(3),151-156.

Bentler P.M. (1990). Comparative Fit Indexes In Structural Models. Psychology Bull; 107: 238-246.

Berry L.L, Seiders K, Grewal D. (2002). Understanding Service Convenience. Journal of Marketing;66:1-17 [July].

Biener L, Mccallum-Keeler G, Nyman A. L. (2000). Adults' Response To Massachusetts Anti-Tobacco Television Advertisement: Impact of Viewer and Advertisement Characteristics. Tobacco Control: 9: 401-7.

Borden, N. H. (1965). The Concept Of The Marketing Mix. In Schwartz, G. (Ed), Science in Marketing. New York: John Wiley \& Sons, 386-397.

Booms B. H.\& Bitner B.J.(1980). Marketing Strategies and Organisation Structures for Service Firms. In Donnelly, J. \& George W. R. (Eds.), Marketing of Services. American Marketing Association, 47-51. Centers For Disease Control And Prevention (2002). Annual Smoking-Attributable Mortality, Years of Potential Life Lost, and the Economic Costs - United States, 1995-1999. Morb Mortal;51:300-3 [April]. Chaiken S. In:

Zanna M.P, Olson J.M, Herman CP, ( 1987). The Heuristic Model of Persuasion. Social Influence: The Ontario Symposium, Hillsdale, NJ: Erlbaum;. P. 3-39.

Chong, K. W. (2003). The Role of Pricing In Relationship Marketing - A Study Of The Singapore Heavy Equipment Spare Parts Industry, Phd Dissertation, International Graduate School of Management, University of South Australia. 
European Journal of Logistics, Purchasing and Supply Chain Management

Vol.8 No.1, pp.1-14, March 2020

Published by ECRTD UK

ISSN 2054-0930 (Print), ISSN 2054-0949 (Online)

Comm C.L. (1997). Demarketing Products Which May Pose Health Risks an Example of the Tobacco Industry. Health Marketing Quarterly;15(1):95-102.

Cox R. (1959). Consumer Convenience and the Retail Structure of Cities. Journal of Marketing;24:355-81 [April].

Craig-Lees M.(2006). Anti-Consumption Concept Clarification And Changing Consumption Behavior International Entre for Anti-Consumption Research (ICAR) Symposium, Http://Www.Business.Auckland.Ac.Nz/Comwebcontent/Docs/Anticonsumption\%20concept\%20clarifi cation.Pdf.Cullwick D. Positioning Demarketing Strategy. Journal of Marketing ;39(2):51-7.

Debono M, Schembri K, Manché A. (2004). Smoking Cessation after Counselling In Subjects Undergoing Coronary Revascularisation. Malta Medical Journal ;16:24-8.

Diclente, C.C; Aska, J.O; Fairhurst, S; Velicer, W.F; Rossi, J.S and Velaquez (1991). The Process Of Smoking Cessation: An Analysis of Precontemplation, Contemplation and Contemplation Action. Journal of Consulting Clinical Psychology;59:295-304.

Eagly A.H, Chaiken S. (1993). The Psychology of Attitudes. Orlando, FL: Harcourt Brace Jovanovich College;

Engleman S. (1987). The Impact of Mass Media Anti-Smoking Publicity. Health Promote;2(1):63-74.

Erickson G.M, Johansson J.K.( 1985). The Role of Price in Multi-Attribute Product Evaluations. Journal of Consumer Research;1(2):195-9.

Ezzati M, Lopez A.D.( 2003). Estimates of Global Mortality Attributable to Smoking in 2000. Lancet;362:84752.

Gerstner E, Hess J, Chu W. (1993). Demarketing as Differentiation Strategy. Marketing Letters;4(1):49-57.

Gilbert R.G, Hannan L. L Lowe K.B. (1998). Is Smoking Stigma Clouding the Objectivity of Employee Performance Appraisal? Public Pesr Manage 1998: 27(3): 285-327.

Goldman L.K, Glantz S.A. Evaluation of Antismoking Advertising Campaigns. .Journal of American Medical Association;279(10):772-7.

Goldsmith R. E. (1999). The Personalised Marketplace: Beyond the 4Ps. Marketing Intelligence and Planning, 17(4), 178-185.

Haley R.I, Baldinger A.L. (1991).The ARF Copy Research Validity Project. Journal Of Advertising Research;31:11-32.

Hassan L.M, Walsh G, Shiu E, Hastings G, Harris F. (2007). Modeling Persuasion In Social Advertising- A study of Responsible Thinking in Antismoking Promotion In Eight Eastern EU Member States. Journal Of Advertising;36(2):15-31.

Hoek J.( 2004). Tobacco Promotion Restrictions: Ironies And Unintended Consequences. Journal of Business Research;57:1250-7.

Hu L, Bentler P.M.( 1999). Cutoff Criteria For Fit Indices In Covariance Structural Analysis: Conventional Criteria Versus New Alternatives. Struct Equ Modeling;6(1):1-56.

Hughes, J.R, Stead, L.F, Lancaster T.( 2004). Anti-depressant for Smoking, CessationCochrane Review. The Cochrane Library. Issue 2; 2003. Oxford: Update software Hyland.

Jacoby J, Olson JC, (1985).Editors. Perceived Quality: How Consumers View Stores And Merchandise. Lexington, MA: Lexington Books.

Judd V. C. (1987). Differentiate With the 5th P: People. Industrial Marketing Management, 16(4), $241-247$. Johnson, K., (2006).Spain's Smoking Establishment Would Rather Fight than Quit - Big Tobacco Slashes Prices, Bars Defy New Laws. The Wall Street Journal Europe;24(38):1 \& 10. 
European Journal of Logistics, Purchasing and Supply Chain Management

Vol.8 No.1, pp.1-14, March 2020

Published by ECRTD UK

ISSN 2054-0930 (Print), ISSN 2054-0949 (Online)

Kent, T. \& Brown, R. B. (2006). Erotic Retailing In The UK (1963-2003) - The View from the Marketing Mix. Journal of Management History, 12(2), 199-211

Kotler, P. (1984). Marketing Management: Analysis, Planning and Control (5th Ed.). New Jersey: Prentice-Hall.

Kotler, P. (1986). Principles of Marketing (3rd Ed.). New Jersey: Prentice Hall

Kotler P, Levy S.J. (1971). Demarketing, Yes, Demarketing. Harvard Business Review;49(6): 74-80.

Lader D, Goddard E.( 2004). Smoking-Related Behaviour and Attitudes, 2003. 185774571X. London: Office for National Statistics;.

Lancaster T, Stead L, Silagy C, Sowden A. (2000). Effectiveness Of Interventions To Help People Stop Smoking: Findings From The Cochrane Library. British Medical Journal;321:355-8.

Lawther S, Hastings G.B, Lowry R. (1997). De-Marketing: Putting Kotler and Levy's Ideas Into Practice. Journal Of Marketing Management;13(4):315-25.

Lazer, W. \& Kelly, E. K. (1962). Managerial Marketing: Perspectives and Viewpoints. IL: Richard D. Irwin.

Lee J.M, Liao D-S, Ye C-Y, Liao W-Z.( 2005). Effect of Cigarette Tax Increase on Cigarette Consumption in Taiwan. Tobacco Control;14:71-5.

Lee, M.S.W, Fernandez, K, Hyman, M.R. Anti-Consumption: An Overview and Research Agenda. Journal of Business Research; Special Issue on Anti-Consumption .

Levy D.T, Chaloupka F, Gitchell J.( 2004). The Effects of Tobacco Control Policies on Smoking Rates: A Tobacco Control Scorecard. Journal of Public Health Management Practise;10(4):338-53.

Maxwell S. (2002). Rule-Based Price Fairness and its Effect on Willingness to Purchase. Journal Of Economics Psychology;23(2):191-212.

Mcmillan B, Conner M.( 2003). Using The Theory of Planned Behaviour to Understand Alcohol and Tobacco Use in Students. Psychology Health Medicine;8:317-28.

Mccarthy, E.J. (1964). Basic Marketing, IL: Richard D. Irwin. Moan IS, Rise J. Quitting Smoking: Applying an Extended Version of The Theory of Planned Behavior to Predict Intention and Behavior. Journal of Applied Behavavior Research;10(1):39-68.

Möller, K. (2006). The Marketing Mix Revisited: Towards the 21st Century Marketing by E. Constantinides. Journal of Marketing Management, 22(3), 439-450.

Moore R.S. (2005). The Sociological Impact of Attitudes Toward Smoking: Secondary Effects of the Demarketing of Smoking. Journal of Social Psychology: 145(6): 703-18.

Niaura R, and Abrams D.B.( 2002). Smoking Cessation: Progress, Priorities, and Prospect. Journal of Consulting Clinical Psychology; 7o: 494-509.

Page CM, Colby PM. (2003). If Only I Hadn't Smoked: The Impact of Counterfactual Thinking on a SmokingRelated Behavior. Psychology and Marketing;20(11): 955-76.

Pechmann C, Knight S.J. (2002). An Experimental Investigation of the Joint Effects of Advertising and Peers On Adolescents' Beliefs And Intentions About Cigarette Consumption. Journal of Consumer Research;29:5-19.

Petty R.E, Cacioppo J.T.( 1981). Attitudes and Persuasion: Classic and Contemporary Approaches. Dubuque, IA: Brown;

Petty R.E, Cacioppo J.T. (1986). Communication And Persuasion: Central and Peripheral Routes to Attitude Change. New York.

Pretty R.E, Krosnick J.A, (1995). Attitude Strength: Antecedents and Consequences. Mahwah, NJ: Erlbaum;. Petty R.E, Ostrom T.M, Brock T.C, (1981). Cognitive Responses in Persuasion. Hillsdale, NJ: Erlbaum;. 
Petty R.E, Haugtvedt C.P, Smith SM.( 1995). Elaboration as a Determinant of Attitude Strength: Creating Attitudes That Are Persistent, Resistant, and Predictive of Behavior. In: Petty RE, Krosnick JA, Editors. Attitude Strength: Antecedents And Consequences. Mahwah, NJ: Erlbaum;. P.93-130.

Romer D, Jamieson P. (2001). Advertising, Smoker Imagery, and the Diffusion of Smoking Behavior. In: Slovic P, Editor. Smoking: Risk, Perception and Policy. Thousand Oaks, CA: Sage; P. 127-58.

Saffer H, Chaloupka F. (2000). The Effect of Tobacco Advertising Bans on Tobacco Consumption. Journal Of Health Economics; 19:1117-37.

Siegel M, Biener L.( 2000). The Impact of an Antismoking Media Campaign on Progression to Established Smoking: Results of a Longitudinal Youth Study. American Journal of Public Health;90(3):380-6.

Silagy C, Stead L.F. (2003). Physician Advice for Smoking Cessation, Cochrane Review. The Cochrane Library. Issue 2;. Oxford: Update Software. Silargy C, Lancaster T, Stead L, Mant D,Fowler G.( 2003). Nicotine Replacement Therapy for Smoking Cessation ,Cochrane Review. The Cochrane Library. Issue 2; Oxford: Update Software.

Stead L, Lancaster T.( 2003). Group Behaviour Therapy Programmes For Smoking Cessation, Cochrane Review. The Cochrane Library. Issue 2;. Oxford: Update Software.

Steiger J.H. (1990). Structural Model Evaluation and Modification: An Interval Estimation Approach. Multivariate Behavior Research: 25: 173-80.

Tesser A. In: Berkowitz L, (1990). Self-Generated Attitude Change. Advances in Experimental Social Psychology. New York: Academic Press; 1978. P. 289-338.

Tesser A, Shaffer D.(1991). Attitudes and Attitude Change. Annual Review Psychology; 41: 479-523.

Thompson M.E, Fong G.T, Hammond D, Boudreau C.D.P, Hyland A, Borland R, (2006). Methods of the International Tobacco Control (ITC) Four Country Survey. Tobacco Control 2006; 15( Suppl.3):Iii128. Doi:10.1136/Tc.2005.013870.

Thrasher J.F, Jackson C.(2006). Mistrusting Companies, Mis-trusting the Tobacco Industry: Clarifying The Context Of Tobacco Prevention Efforts that Focus on the Tobacco Industry. Journal of Health And Social Behavior;47(4):406-22.

U.S. Federal Trade Commission (2006). Federal Trade Commission's Cigarette Report for 2002.

Varian HR.( 1993). Intermediate Microeconomics: A Modern Approach. $3^{\text {rd }}$ Ed. New York, NY: W.W. Norton \& Company.

Wakefield M, Chaloupka F.J. (2000). Effectiveness of Comprehensive Tobacco control Programs In Reducing Teenage Smoking In The USA. Tobacco Control: 9: 177-86. 